\title{
Diagnostic Yield of PAX5 in Lymphoma
}

\author{
Hiba Rafea* , Abdul Kareem Yonis Al-Tae ${ }^{\star \star}$, Nazar Mohamed Jawhar*** \\ *Postgraduate Student, Department of Pathology, College of Medicicn, University of Mosul \\ **Department of Pathology College of Medicine , University of Mosul , ${ }^{* \star *}$ Department of Pathology, \\ College of Medicine, University of Nineveh, Mosul, Iraq \\ Correspondence: h.r.t.m.w.t@gmail.com
}

(Ann Coll Med Mosul 2020; 42 (2):109-118).

Received: 20 $0^{\text {th }}$ Oct. 2020; Accepted: $6^{\text {th }}$ Dec. 2020.

\begin{abstract}
Background: Lymphoma is a heterogeneous group of neoplasm affecting any stage of lymphocyte development. Nowadays, WHO (2017) adapted their classification depending on their morphological, immunohistochemical appearance, and their clinical and molecular characteristics.

Objective: To determine the expression of PAX5 in Hodgkin and Non Hodgkin lymphoma and their association with clinical parameters (age \& site).

Patients \& Methods: During a period of 1 year starting from June 2019 to June 2020, 60 lymphoma patients were included in this prospective-retrospective case series study from medical records and histopathological results in governmental and private labs. Immunohistochemistry examination using PAX5 was performed, and data of the positive PAX5 expression were analyzed.

Results: A total of 60 patients were recruited in this study with the majority (58\%) were Non Hodgkin lymphoma, dominated by diffuse large B- cell lymphoma subtype $(42.8 \%)$ and $(42 \%)$ were Hodgkin lymphoma where nodular sclerosis subtype formed $(52 \%)$ and mainly of the nodal site in both of them. The age range of Non Hodgkin lymphoma 7-76 years (median 50 years) and 5-67 years (median 21 years) for Hodgkin lymphoma and male predominance in both of them and there is no significant association between the site and lymphoma ( $p$ value $=0.0647$ ) while a significant association with age ( $p$ value $=0.037$ ). Moreover, the immunohistochemical examination demonstrates that positive PAX5 was expressed in $77 \%$ of Non Hodgkin lymphoma and $100 \%$ of Hodgkin lymphoma. The P-value between them was 0.016 , which was statistically significant ,no matter of using PAX5 or CD30 in the diagnosis of Hodgkin lymphoma,in other hand there is a significant difference between PAX5 and CD3 expression ( $P$ value $=0.004$ ), while it is not statistically significant when comparing PAX5 and CD20 (P-value $=0.317$ ) in the diagnosis of Non Hodgkin lymphoma.
\end{abstract}

Conclusion: This study demonstrates that PAX5 is one of the most sensitive and reliable immunohistochemical marker in diagnosing Hodgkin lymphoma and B-cell Non Hodgkin lymphoma.

Keywords: Hodgkin lymphoma, Immunohistochemistry, Non Hodgkin lymphoma, PAX5.

$$
\begin{aligned}
& \text { ألعائد ألتشخيصى لمعلمة باكس ه فى اورام الغدد اللمفاوية }
\end{aligned}
$$

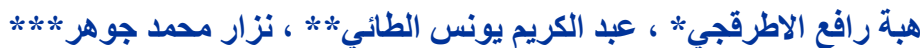

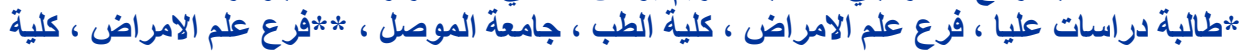

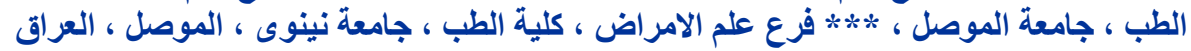

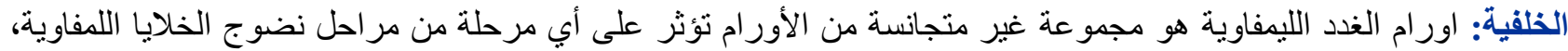

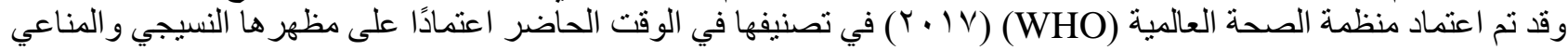

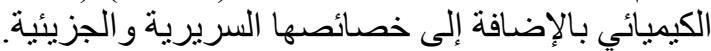
الههاف: تحديد معلمة الاور ام باكسه في اورام الغدد الليمفاوية ونسبة انتشار ها لاور ام الهودجكن و اللاهودجكن و التر ابط السريري 


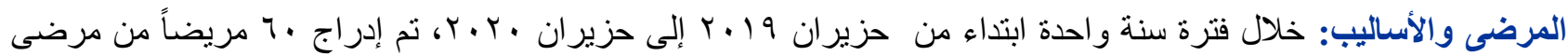

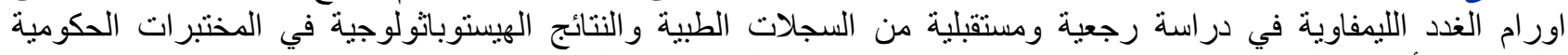

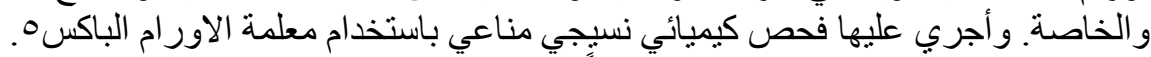

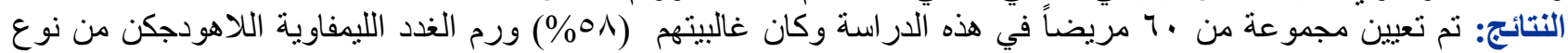

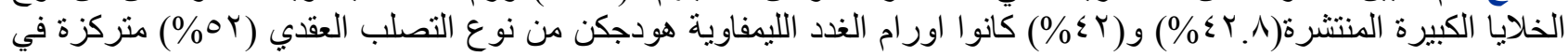

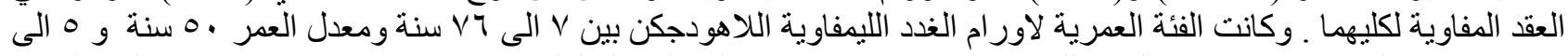

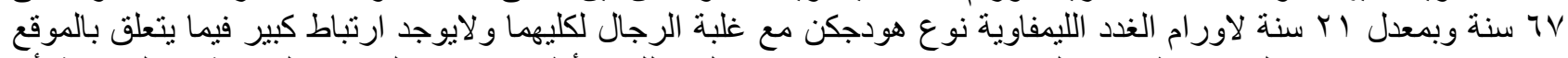
( باكسئ0.647) بينما هنالك ارتباط مع العمر (P=0.037).

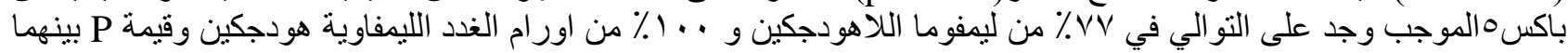

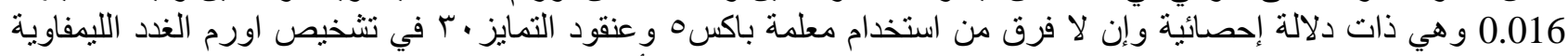

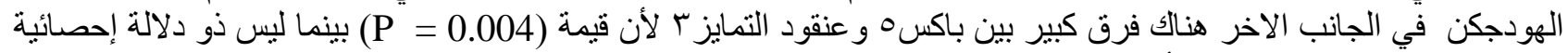

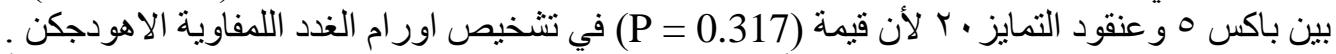

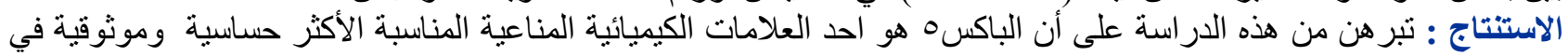

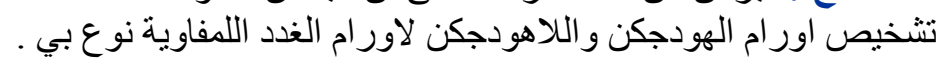

الكلمات المفتاحية : اور ام هودجكن , الفحص الكيميائي النسيجي المناعي, اور ام اللاهودجكن , باكس॰.

\section{INTRODUCTION}

ymphoma is a heterogeneous group of - malignant tumors of lymphoid cells at different maturation stages, which could be nodal or extranodal. The World Health organization's (WHO) classification system recognizes more than 90 different subtypes, and it classifies lymphoma into Hodgkin (HL) and Non Hodgkin lymphoma (NHL). ${ }^{1}$

Lymphoid neoplasms occupy the sixth leading cause of cancer related death in the United States in 2016 as there are 136,960 new cases diagnosed annually. ${ }^{2}$

The category of $\mathrm{HL}$ encompasses classical Hodgkin lymphoma (CHL) and less commonly nodular lymphocyte-predominant Hodgkin lymphoma (NLPHL), and the diagnosis of them depends on the presence of neoplastic Hodgkin Reed-Sternberg (HRS) cells. ${ }^{3}$ and lymphocyte predominant (LP) cells within the reactive inflammatory background respectively. ${ }^{4}$ Both of these types arise from germinal center Bcell. ${ }^{5}$

NHL comprises of different neoplasm of the immune system, Eighty-five to ninety percent of them are derived from B- cell, while $10-15 \%$ are derived from $T$ cell or NK cell. ${ }^{6}$

Immunohistochemical (IHC) markers are crucial for recognition of the B-cell lineage to help in the diagnosis and classification of lymphoma ${ }^{7}$ due to overlapping morphology and antigenic variation. ${ }^{8}$ Accurate lineage assignment has contributed to our fundamental understanding of lymphoma and advances in therapeutic and disease monitoring strategies.
IHC detection of PAX5 protein, also known as Bcell specific activation protein (BSAP), in lymphoid neoplasm using polyclonal and monoclonal antibodies was used as a well-identified marker for recognizing the $B$-cell lineage cells. ${ }^{9,10}$

The BSAP protein is encoded by the PAX5 gene 11, which is located in 9p13 chromosome 12 . It consists of a family of 9 members (PAX1-PAX9) arranged into four groups ( I, II, III, and IV) according to their structural similarity. It has a significant role in regulating cell migration, proliferation, and differentiation through organogenesis. $^{13}$

PAX5 protein is a subgroup II member of highly conserved paired box (PAX) family, and the only member that involved in the hematopoietic system 13 that is important for cellular commitment, immunoglobulin rearrangement, pre BCR (B cell receptor) signaling, and survival of mature $B$ - cell. ${ }^{14}$ in addition to functional maintenance of $B$ - cell during late $B$ lymphopoiesis. ${ }^{15}$

PAX5 is expressed primarily in pro-, pre- and mature B-cells but not in plasma cells. ${ }^{16}$

\section{Aim of the Study}

To find the frequency of PAX5 expression in lymphoma (HL \&NHL) and its association with clinicopathological parameters (age and site).

\section{MATERIAL AND METHODS}

This study was reviewed and approved by the Medical Research Ethnics Committee (MREC), College of Medicine, University of Mosul. In this case series study, extending over one year from June 2019 through June 2020, all cases diagnosed 
as lymphoma at governmental hospitals and those referred from private laboratories in Nineveh province in the North of Iraq were enrolled in this current study.

The study includes 60 cases of lymphoma. All histopathological reports were reviewed regarding clinicopathological data (age, gender, and site). For each case, the author reviewed the hematoxylin and eosin-stained sections. The tumor was diagnosed and subtyped according to the WHO classification system 2017. ${ }^{1}$ One section from each case was selected for the immunohistochemical study.

\section{Immunohistochemistry:}

Each case was studied for PAX5 expression. Formalin-fixed paraffin-embedded block of cases were obtained. Section of 5 microns thick were deparaffinized in xylene and rehydrated. The immunohistochemical study was performed according to manufacturer instructions using the IgG rabbit monoclonal antibody (Clone: EP156 PR064-3ml RTU, Pathnsitu company, India), and PathnSitu PolyExcel detection system with DAB chromogen. Positive and negative control slides were involved in each run of staining. Negative controls were prepared by replacing the primary antibody with Tris-buffered saline; positive control slides were obtained from tonsil.

For the evaluation of PAX5 expression, histopathological features were correlated with cell specific immunohistochemical staining pattern and are compared with the control slides. Nuclear brown color staining in more than $10 \%$ of neoplastic cells is regarded as positive, ${ }^{17}$ and the expression of PAX5 in normal $B$ - cell is more strong than HRS, which is faint. ${ }^{18}$

Apart from PAX5, which was done in 60 patients, other IHC markers reports were obtained from several cases of the same patients in our study. The results of immunohistochemical markers CD30, CD3, CD20 previously used to confirm the diagnosis and subtyping of lymphoma were studied and determined as positive or negative to obtain the association between them and PAX5 expression.

The immunohistochemical markers and clinicopathological variables were analyzed using the Statistical Package for Social Science version 23 SPSS and association between PAX5 expression and variable categories, and other markers were evaluated using the Fisher Exact test and McNemar Chi-square test when indicated, and the probability level accepted for significance was $P<0.05$.

\section{RESULTS}

Among 60 cases included in this study, 25 (42\%) cases were diagnosed as $\mathrm{HL}$, whereas 35 cases (58\%) diagnosed as NHL

As shown in Table (1). The age of $\mathrm{HL}$ patients ranged from 5-67 years (mean $26 \pm 14.73$ ) years (median 21 years) peaked at the teenage group (36\%). Patient's age in NHL ranged from 7-76 years (mean $46 \pm 18.72$ ) (median 50 years) peaked at the fifth decade $(31.5 \%)$, with male to female ratio of 1.2: 1

There was a statistically significant association between PAX5 and age ( $P$ value $=0.037$ ).

Table (2) showing the histopathological subtyping of lymphoma which revealed nodular sclerosis (figures 1\&2) was the commonest $\mathrm{HL}$ subtypes $13 / 25$ (52\%) of cases, followed by mixed cellularity $11 / 12(44 \%)$ then a single case of lymphocyte predominant HL whereas diffuse large B-cell lymphoma (figures 3\&4) dominated NHL cases $15 / 35$, forming $(42.8 \%)$ of $\mathrm{NHL}$ cases followed by 3 cases (8.6\%) of each small lymphocytic lymphoma, lymphoblastic lymphoma (figures 5\&6), follicular lymphoma (figures 7\&8), marginal zone lymphoma (figures $9 \& 10$ ), then 2 cases $(5.7 \%)$ of each Burkitt lymphoma (figures 11\&12), lymphoplasmacytic lymphoma, peripheral T-cell lymphoma and single cases (2.85\%) of mantle cell lymphoma and large unclassified cases.

PAX5 was expressed in all 25 cases of $\mathrm{HL}$, whereas it showed positivity in 27 out of $35(77 \%)$ and negative in 8 cases $(23 \%)$ of $\mathrm{NHL}$ with a significant statistical association between them $(P=0.016)$ as shown in table (3).

Most of the NHL were of $\mathrm{B}$ - cell lineage $30 / 35$ (85.7\%), and they were much more than $\mathrm{T}$ - cell lineage $4 / 35(11.4 \%)$, while one case $(2.9 \%)$ was not classified under a specific cell type and was reported as unclassifiable $\mathrm{NHL}$. PAX5 has been observed in $27 / 30$ cases (90\%) of B-cell NHL while it was negative in all T-cell lymphoma 4/4 (100\%) and the single unclassifiable case.

Regarding the location, $82 \%$ of $\mathrm{NHL}$ were nodal, and $18 \%$ were extranodal .while all $\mathrm{HL}$ cases were nodal, and it has been shown the association of PAX5 expression in relation to the site does not show statistically significant value $(P=0.647)$ as shown in table (4).

CD 30 expression results were available in 14 cases of $\mathrm{HL}$, and all of them have expressed PAX5, as shown in table (5).

In NHL of a paired match group, CD3 results were also available in 22 cases of $\mathrm{NHL}$ (18 were negative and 4 were positive). PAX5 was expressed in only 17 cases of them $(77.3 \%)$, and the P-value between them was 0.004 , which is statistically significant as shown in table (6). These 
cases consisting of $1 / 4$ (25\%) case of PAX5 positive and CD3 positive whereas the other $3 / 4$ (75\%) cases showing PAX5 negative and CD3 positive while there is $2 / 18(11 \%)$ showing simultaneous negativity and 16/18 (89\%) showing positive PAX5 and negative CD3 as shown in Table (6)

PAX5 was found to be positive in 20/26 (77\%) in $\mathrm{NHL}$ in paired match cases, and the positivity for CD20 was found to be $21 / 26(81 \%)$, and the Pvalue between them was 0.317 , which is statistically not significant as shown in table (7).

Table (1): Age distribution of lymphoma patients.

\begin{tabular}{|l|l|l|l|l|}
\hline \multirow{2}{*}{$\begin{array}{l}\text { Age groups } \\
\text { (years) }\end{array}$} & \multicolumn{2}{|l|}{$\begin{array}{l}\text { Hodgkin } \\
\text { lymphoma }\end{array}$} & \multicolumn{2}{l|}{$\begin{array}{l}\text { Non-Hodgkin } \\
\text { lymphoma }\end{array}$} \\
\cline { 2 - 5 } & No. & $\%$ & No. & $\%$ \\
\hline$<10$ & 1 & 4.0 & 2 & 5.7 \\
\hline $10-19$ & 9 & 36.0 & 3 & 8.6 \\
\hline $20-29$ & 8 & 32.0 & 0 & 0.0 \\
\hline $30-39$ & 2 & 8.0 & 4 & 11.4 \\
\hline $40-49$ & 2 & 8.0 & 6 & 17.1 \\
\hline $50-59$ & 2 & 8.0 & 11 & 31.5 \\
\hline$\geq 60$ & 1 & 4.0 & 9 & 25.7 \\
\hline Total & 25 & 100.0 & 35 & 100.0 \\
\hline
\end{tabular}

Table (2): Frequencies of different lymphoma types in the current study.

\begin{tabular}{|l|l|l|}
\hline Final Diagnosis & No. & $\begin{array}{l}\text { Percentage } \\
(\%)\end{array}$ \\
\hline Hodgkin Lymphoma & & \\
\hline A. Classical HL & & \\
\hline Nodular Sclerosis & 13 & 52.0 \\
\hline Mixed cellularity & 11 & 44.0 \\
\hline $\begin{array}{l}\text { Nodular lymphocyte } \\
\text { predominant }\end{array}$ & 1 & 4.0 \\
\hline Total & 25 & 100.0 \\
\hline Non-Hodgkin Lymphoma & 15 & 42.8 \\
\hline $\begin{array}{l}\text { Diffuse large B-cell } \\
\text { lymphoma }\end{array}$ & 3 & 8.6 \\
\hline Follicular lymphoma & 3 & 8.6 \\
\hline $\begin{array}{l}\text { Small lymphocytic } \\
\text { lymphoma }\end{array}$ & 3 & 8.6 \\
\hline Marginal zone lymphoma & 3 & 8.6 \\
\hline Lymphoblastic lymphoma & 2 & 5.7 \\
\hline Burkitt lymphoma & 2 & 5.7 \\
\hline $\begin{array}{l}\text { Lymphoplasmacytic } \\
\text { lymphoma }\end{array}$ & 1 & 2.85 \\
\hline Mantle cell lymphoma & 2 & 5.7 \\
\hline $\begin{array}{l}\text { Peripheral T-cell } \\
\text { lymphoma }\end{array}$ & 1 & 2.85 \\
\hline Large unclassified & 35 & 100.0 \\
\hline Total & \\
\hline
\end{tabular}

Table (3): PAX5 expression in lymphoma in the current study

\begin{tabular}{|c|c|c|c|c|c|}
\hline \multirow{2}{*}{$\begin{array}{l}\text { Types of } \\
\text { lymphoma }\end{array}$} & \multicolumn{2}{|c|}{$\begin{array}{l}\text { PAX5 } \\
\text { Positive }\end{array}$} & \multicolumn{2}{|c|}{$\begin{array}{l}\text { PAX5 } \\
\text { Negative }\end{array}$} & \multirow{2}{*}{$\begin{array}{l}\text { P- } \\
\text { value }\end{array}$} \\
\hline & No & $\%$ & No & $\%$ & \\
\hline $\begin{array}{l}\text { Hodgkin } \\
\text { lymphoma } \\
(n=25)\end{array}$ & 25 & 100.0 & 0 & 0.0 & \multirow[b]{2}{*}{0.016} \\
\hline $\begin{array}{l}\text { Non } \\
\text { Hodgkin } \\
\text { lymphoma } \\
(n=35)\end{array}$ & 27 & 77.0 & 8 & 23.0 & \\
\hline
\end{tabular}

Fisher Exact test was used.

Table (4): PAX5 expression in relation to the site of lymphoma

\begin{tabular}{|l|l|l|l|l|l|}
\hline \multirow{2}{*}{ Site } & \multicolumn{2}{|l|}{$\begin{array}{l}\text { PAX5 } \\
\text { Positive }\end{array}$} & \multicolumn{2}{l|}{ PAX5 } & \multirow{2}{*}{$\begin{array}{l}\text { Negative } \\
\text { value }\end{array}$} \\
\cline { 2 - 5 } & No & $\%$ & No & $\%$ & \\
\hline Nodal $(n=49)$ & 42 & 85.7 & 7 & 14.3 & \multirow{2}{*}{0.647} \\
\hline $\begin{array}{l}\text { Extranodal } \\
(n=11)\end{array}$ & 10 & 90.9 & 1 & 9.1 & \\
\hline
\end{tabular}

Chi-square test was used.

Table (5): Associations between PAX5 \& CD30 in 14 cases of $\mathrm{HL}$

\begin{tabular}{|l|l|l|l|l|l|}
\hline \multirow{2}{*}{ IHC } & \multicolumn{2}{|l|}{$\begin{array}{l}\text { Positive } \\
\text { cases }\end{array}$} & \multicolumn{2}{l|}{$\begin{array}{l}\text { Negative } \\
\text { cases }\end{array}$} & \multirow{2}{*}{$\begin{array}{l}\text { P- } \\
\text { value }\end{array}$} \\
\cline { 2 - 5 } & No. & $\%$ & No. & $\%$ & val \\
\hline PAX5 $(n=14)$ & 14 & 100.0 & 0 & 0.0 & \\
\hline CD30 $(n=14)$ & 14 & 100.0 & 0 & 0.0 & ---- \\
\hline
\end{tabular}

Table (6) Test analysis results for 22 cases PAX5 $\&$ CD3 in a paired group $\mathrm{NHL}$

\begin{tabular}{|c|c|c|c|c|c|c|c|c|}
\hline \multicolumn{2}{|c|}{$\mathrm{IHC}$} & \multicolumn{6}{|c|}{ CD3 } & \multirow[b]{3}{*}{$\begin{array}{l}\text { P- } \\
\text { valu } \\
\mathrm{e}^{*}\end{array}$} \\
\hline & & \multicolumn{2}{|c|}{$+\mathrm{ve}$} & \multicolumn{2}{|c|}{- ve } & \multicolumn{2}{|c|}{ Total } & \\
\hline & & $\begin{array}{l}\mathrm{N} \\
\mathrm{o} .\end{array}$ & $\%$ & $\begin{array}{l}\mathrm{N} \\
\mathrm{O} .\end{array}$ & $\%$ & $\begin{array}{l}\mathrm{N} \\
\mathrm{o} .\end{array}$ & $\%$ & \\
\hline \multirow{2}{*}{$\begin{array}{l}\text { PA } \\
\times 5\end{array}$} & $\begin{array}{l}+ \\
v \\
e\end{array}$ & 1 & $\begin{array}{l}25 . \\
0\end{array}$ & 16 & $\begin{array}{l}89 . \\
0\end{array}$ & 17 & $\begin{array}{l}77 . \\
3\end{array}$ & \multirow{3}{*}{$\begin{array}{l}0.00 \\
4\end{array}$} \\
\hline & $\begin{array}{l}- \\
\mathrm{v} \\
\mathrm{e}\end{array}$ & 3 & $\begin{array}{l}75 . \\
0\end{array}$ & 2 & $\begin{array}{l}11 . \\
0\end{array}$ & 5 & $\begin{array}{l}22 . \\
7\end{array}$ & \\
\hline \multicolumn{2}{|c|}{ Total } & 4 & $\begin{array}{l}10 \\
0\end{array}$ & 18 & $\begin{array}{l}10 \\
0 \\
\end{array}$ & 22 & $\begin{array}{l}100 \\
.0\end{array}$ & \\
\hline
\end{tabular}

${ }^{*}$ McNemar Chi-square test was used. 
Table (7): Association between PAX5 \& CD20 in 26 cases of $\mathrm{NHL}$

\begin{tabular}{|l|l|l|l|l|l|}
\hline \multirow{2}{*}{ IHC } & \multicolumn{2}{|l|}{$\begin{array}{l}\text { Positive } \\
\text { cases }\end{array}$} & \multicolumn{2}{l|}{$\begin{array}{l}\text { Negative } \\
\text { cases }\end{array}$} & \multirow{2}{*}{$\begin{array}{l}\text { P- } \\
\text { value }\end{array}$} \\
\cline { 2 - 5 } & No. & $\%$ & No. & $\%$ & \\
\hline PAX5 $(n=26)$ & 20 & 77.0 & 6 & 23.0 & \multirow{2}{*}{0.317} \\
\hline CD20 $(n=26)$ & 21 & 81.0 & 5 & 19.0 & \\
\hline
\end{tabular}

* McNemar Chi-square test was used.

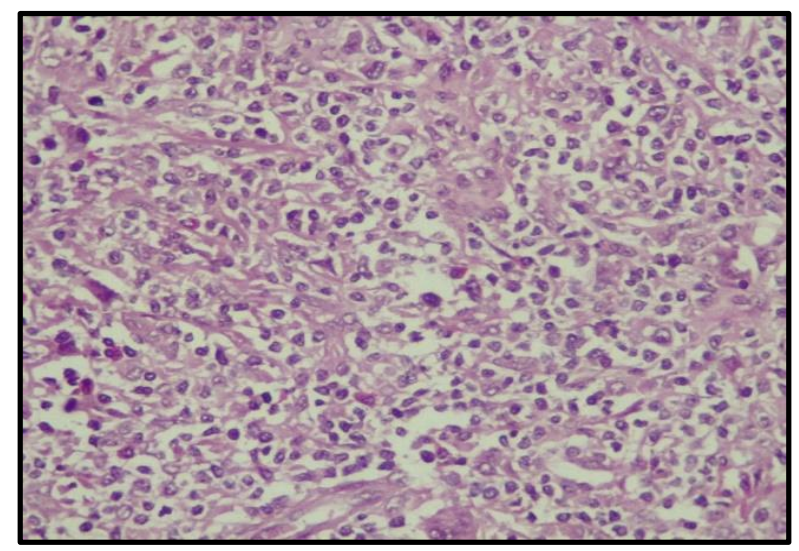

Figure (1): HL-Nodular sclerosis (H\&E x 400)

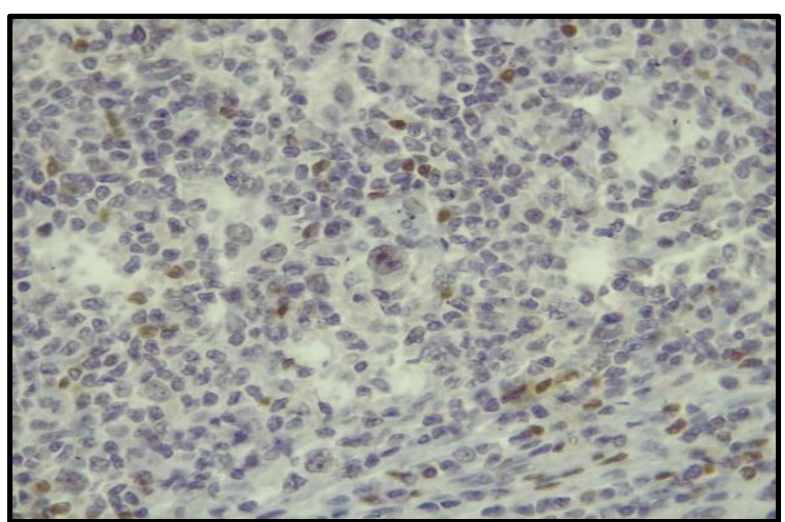

Figure (2): HL-Nodular sclerosis (PAX5positive $\mathrm{x} 400$ )

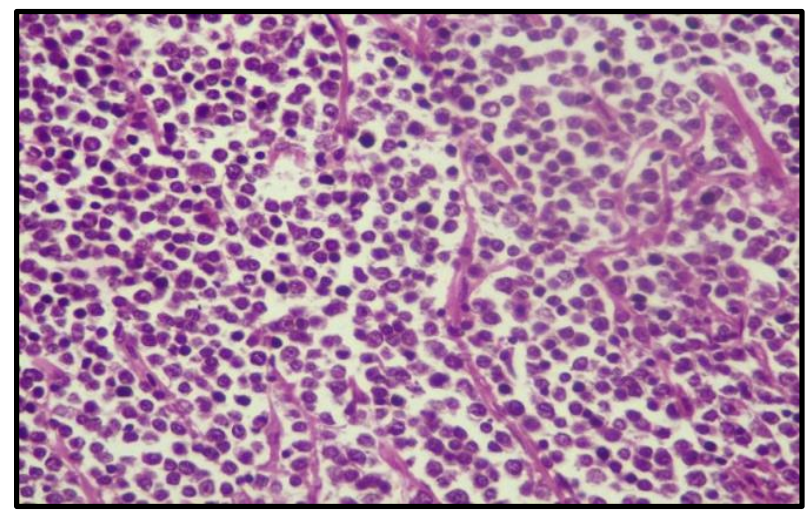

Figure (3): Diffuse large B cell lymphoma (H\&Ex400)

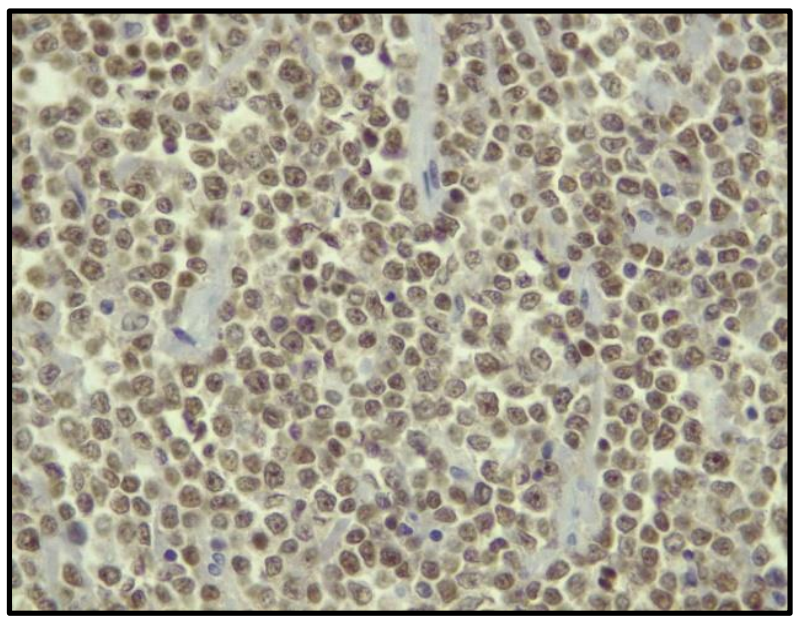

Figure (4): Diffuse large B cell lymphpma (PAX5 positive $\times 400$ )

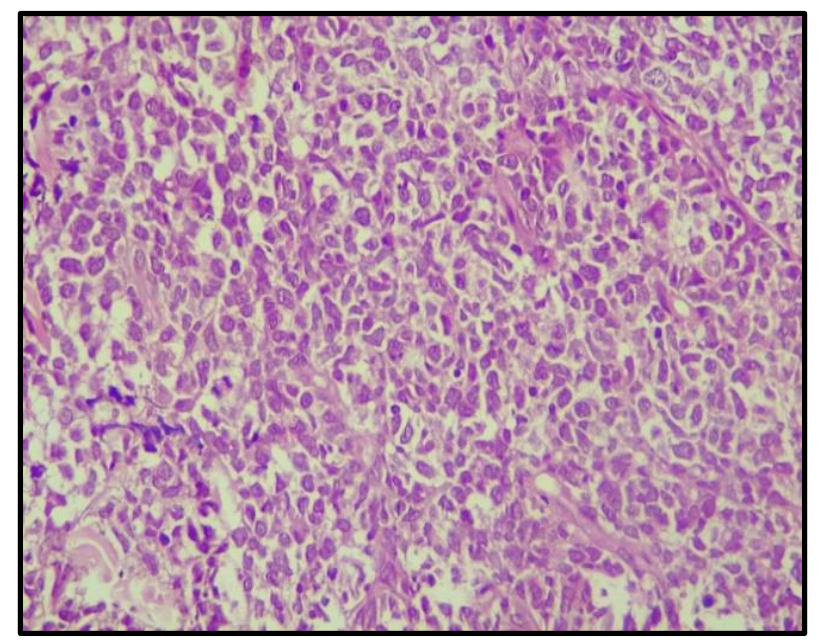

Figure (5): Lymphoblastic Lymphoma (H\&E x400)

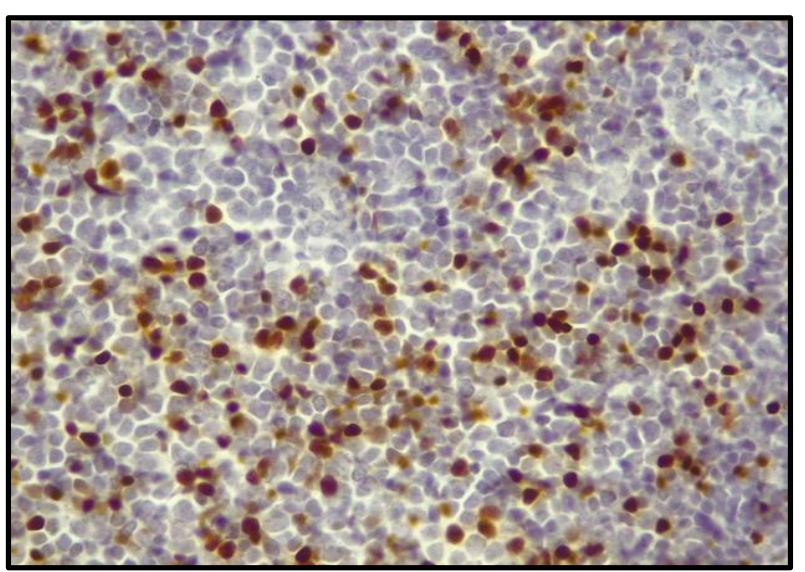

Figure (6): Lymphoblastic Lymphoma (PAX5 positive $\times 400$ ) 


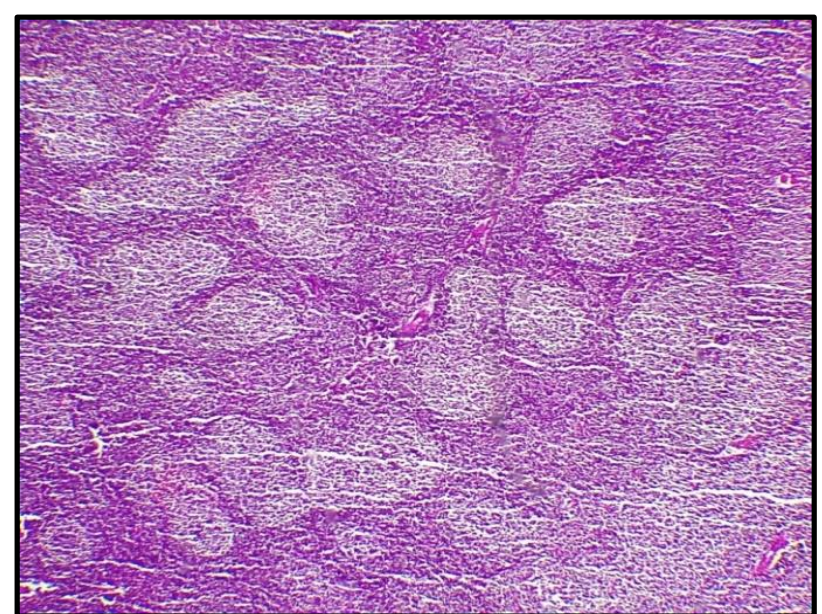

Figure (7): Follicular lymphoma (H\&E x40)

Figure (8): Follicular lymphoma (PAX5 positive $x 40$ )

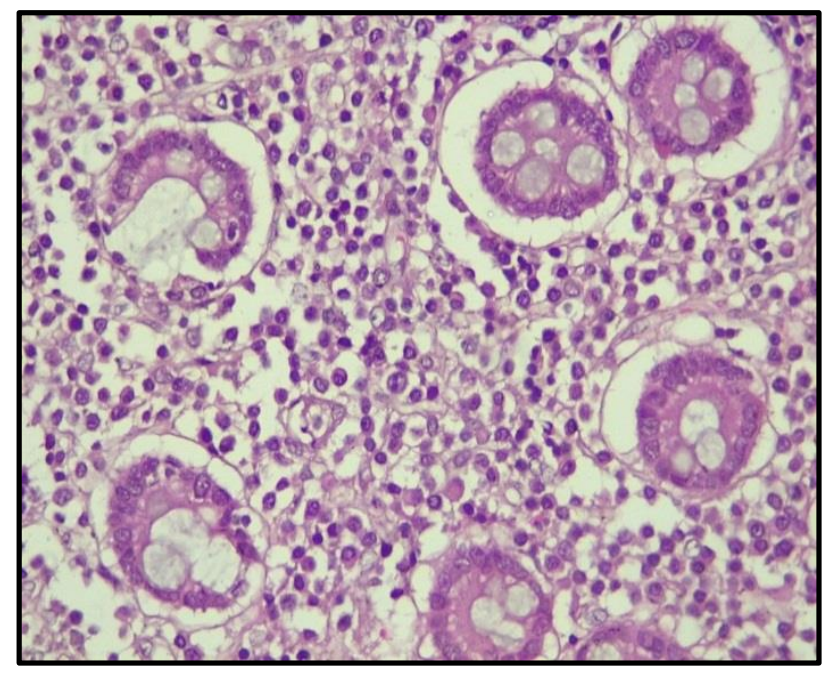

Figure (9): Marginal zone lymphoma (H\&E x400)

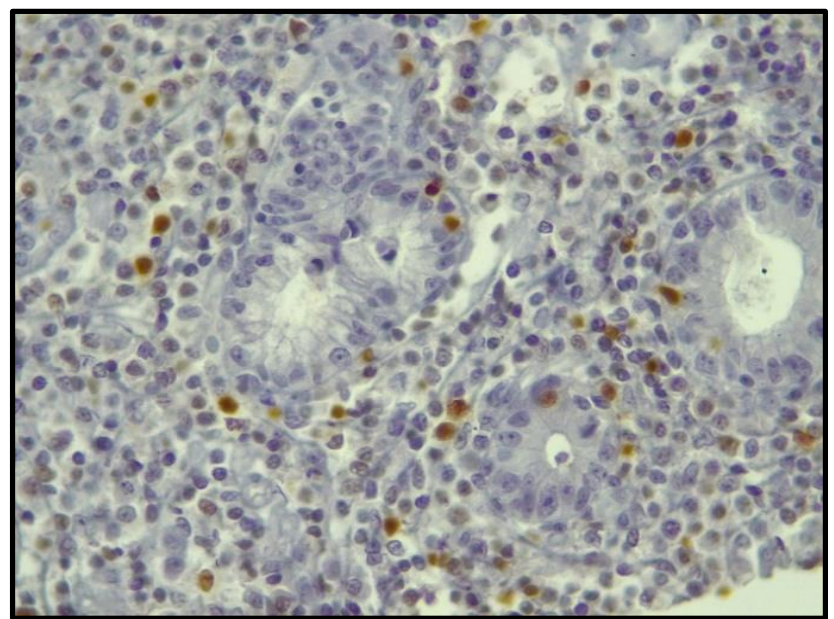

Figure (10): Marginal zone lymphoma (PAX5 positive $\times 400$ )

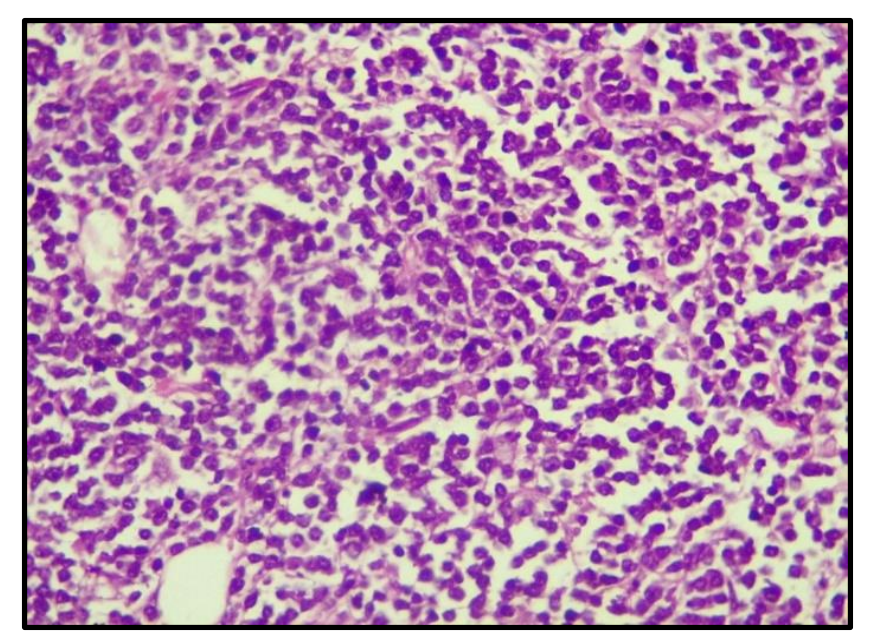

Figure (11): Burkitt lymphoma (H\&E x400)

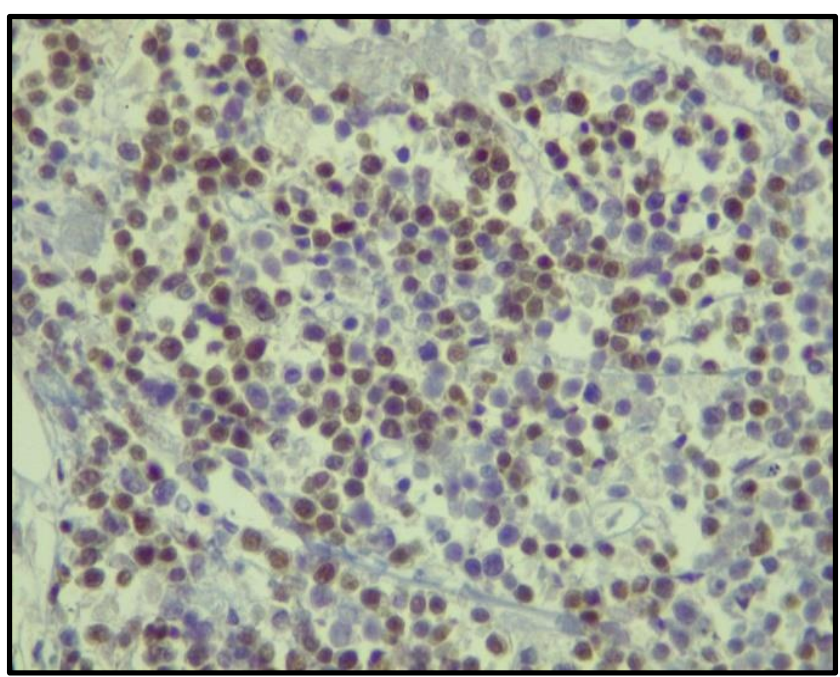

Figure (12): Burkitt lymphoma (PAX5 positive $x 400)$ 


\section{DISCUSSION}

Lymphoma is a group of lymphoid neoplasm with different genetic alterations, immunophenotypes, and clinical features, The prevalence of lymphoma is less in developing countries than in developed countries. ${ }^{19}$ Although the overall incidence is increased worldwide. ${ }^{20}$

$\mathrm{HL}$ is more prevalent cancer in the young age group $^{21}$, as seen in the North of Iraq ${ }^{22}$ in Saudi Arabia $^{23}$ in Pakistan ${ }^{24}$, which is in agreement with the result of this study. The high family number and early exposure to viral infection may be all attributed to the high incidence of $\mathrm{HL}$ in childhood 25 . However, other studies in this locality showed another peak incidence in advanced age ${ }^{26}$ also in Kuwait $^{27}$ in China ${ }^{28}$ and Western and developed countries $^{25}$. In this series, a bimodal series was not apparent. The absence of age-related bimodality might contribute to the rising incidence of nodular sclerosis subtype which is more associated with unimodal distribution ${ }^{29}$ or small sample size. Hence a furthermore extensive study is recommended.

Regarding NHL was found to be more prevalent among patients above 50 years. ${ }^{23}$ and the rate of increasing NHL cases with age has been reduced.

${ }^{30}$ This is in accordance with the result of this study and other studies in Saudi Arabia ${ }^{23}$ and Turkey ${ }^{30}$ but lesser than seen in Pakistan. ${ }^{24}$

We found a statistically significant association between the age of patients and PAX5 expression $(P$-value $=0.037)$

The incidence of lymphoma was higher in males than in females. This has been clearly shown in the current study and in concordance with other studies too. ${ }^{23,31,32}$ Occupational exposure of males contributes to a high-risk factor in males more than females. ${ }^{33}$

In the present study, the recorded NHL cases are more than $\mathrm{HL}$, which is consistent with the results of other studies conducted in the north and south of Iraq ${ }^{31,34}$, and another study in the USA. ${ }^{35}$

The most frequent histological subtype of $\mathrm{HL}$ in the current study was nodular sclerosis (NS) $(52 \%)$, which is similar to another study from Erbil city in the north of Iraq. ${ }^{22}$ but it is different from a study in Misan city in the south of Iraq where the mixed cellularity (MC) is the highest frequency ${ }^{31}$, also in Pakistan ${ }^{24}$, Indonesia ${ }^{36}$, and China ${ }^{28}$. This changing trend might be linked to environmental and host factors and reduced risk of EBV exposure in early childhood that is associated with $\mathrm{MC}$ rather than NS. ${ }^{37}$

Diffuse large B-cell lymphoma (DLBC) has also been reported to be the most common subtypes of $\mathrm{NHL}(42 \%)$. This finding is similar to other series from North and South of Iraq but in different proportions $(52.2 \%)$ (73.3\%), respectively ${ }^{31,34}$ in addition to most studies worldwide. However, it varies considerably from region to region (33.6\%) in Saudi Arabia ${ }^{23}$, (55.7\%) in Bahrain ${ }^{38}$, (78.7\%) in Turkey ${ }^{30}$, (30\%) in Pakistan ${ }^{24},(25 \%)$ in US ${ }^{2}$. These differences might belong to different geographical regions, genetic, lifestyle, and environmental factors. ${ }^{39}$

All the reported cases of $\mathrm{HL}$ in the current study show PAX5 positivity (100\%). A similar finding was noticed by other studies ${ }^{40-44}$ and very low frequency noticed in a study done in North America ${ }^{45}$ in Indonesia ${ }^{36}$ and in Europe ${ }^{46}$. This wide range of detection may be due to the properties of different antibodies, subjectivity in interpretation, ${ }^{47}$ also tissue fixation procedure, protocol variation in the technique of incubation antigen retrieval, as well as the number of cases studied

Most of the studies noticed that PAX5 is expressed in B- cell lineage $\mathrm{NHL}$ in a different higher proportion ${ }^{14,41,44}$ which is similar to this work, that could be attributed to different antibodies used, interpretation results, and differences in population groups.

NHL presents a wider systemic extranodal distribution than $\mathrm{HL}$, and this has been observed in the current study and other studies ${ }^{35,41,44}$ although extranodal $\mathrm{HL}$ can occur in few cases. ${ }^{28,48}$

No significant difference was noted between PAX5 expression and site in this study as well as other studies. ${ }^{40,44}$

\section{CONCLUSION}

PAX5 is a most sensitive and reliable $B$ cell marker in the diagnosis of $\mathrm{HL}$ and $\mathrm{NHL}$. It is expressed in $100 \%$ of $\mathrm{HL}$ cases and $77 \%$ of $\mathrm{NHL}$, and there is a significant difference between PAX5 immunoreactivity with $\mathrm{HL}$ and NHL. There is no significant difference in using PAX5 or CD30 in $\mathrm{HL}$, and there is a significant negative association between PAX5 and CD3 while it is no significant association between PAX5 and CD20 in NHL

$\mathrm{HL}$ was found to be more prevalent among younger age groups while NHL in older people and predominance of male gender in both of them. NS was the most common subtypes of $\mathrm{HL}$, while DLBC lymphoma was the major subtypes of NHL. Lastly, there is mainly nodal involvement in lymphoma cases, and there is no difference of PAX5 immunostaining in relation to the site, but it is significant with age. 


\section{Acknowledgment}

The authors are grateful to Dr. Hatem AbdAlMajeed Al-Nuaimi a supervisor of Arab board pathology-Mosul center for his assistance in immunohistochemistry and to all members of the Department of Pathology, College of Medicine, University of Mosul for their kind cooperation.

\section{REFERENCE}

1.Swerdlow SH, Campo E, Harris NL, Jaffe ES, Pileri SA, Stein $\mathrm{H}$, et al. WHO Classification of Tumours of Haematopoietic and Lymphoid Tissues. Revised 4t. 2017. Lyon, France: IARC; 189-465 p.

2. Teras LR, DeSantis CE, Cerhan JR, Morton LM, Jemal A, Flowers CR. US lymphoid malignancy statistics by World Health Organization subtypes. CA Cancer J Clin. 2016; 66(6):443-59.

3. Agostinelli C, Pileri S. Pathobiology of Hodgkin Lymphoma. Mediterr J Hematol Infect Dis. 2014. 6(1):1-12.

4. Hartmann S, Eichenauer DA. Nodular lymphocyte predominant Hodgkin lymphoma: pathology, clinical course and relation to $\mathrm{T}$ cell/histiocyte rich large B-cell lymphoma. Pathology. 2020; 52(1):142-53.

5. Re D, Küppers R, Diehl V. Molecular pathogenesis of Hodgkin's lymphoma. J Clin Oncol. 2005; 23(26):6379-86.

6. Armitage JO, Gascoyne RD, Lunning MA, Cavalli F. Non-Hodgkin lymphoma. Lancet [Internet]. 2017.390(10091):298-310. Available from: $\quad h t t p: / / d x . d o i . o r g / 10.1016 / S 0140-$ 6736(16)32407-2

7. Disanto MG, Ambrosio MR, Rocca BJ, Ibrahim $\mathrm{HAH}$, Leoncini L, Naresh KN. Optimal minimal panels of immunohistochemistry for diagnosis of B-Cell lymphoma for application in countries with limited resources and for triaging cases before referral to specialist centers. Am J Clin Pathol. 2016. 145(5):687-95.

8. Gill KZ. Mantle cell lymphoma mimicking chronic lymphocytic leukemia/small lymphocytic lymphoma on flow cytometry. J Hematop [Internet]. 2020.13(1):25-31. Available from: https://doi.org/10.1007/s12308-020-00384-x

9. Krenacs L, Himmelmann AW, QuintanillaMartinez L, Fest T, Riva A, Wellmann A, et al. Transcription factor B-cell-specific activator protein (BSAP) is differentially expressed in $B$ cells and in subsets of B-cell lymphomas. Blood. 1998.92(4):1308-16.

10. Torlakovic E, Torlakovic G, Nguyen PL, Brunning RD, Delabie J. The value of anti-Pax-5 immunostaining in routinely fixed and paraffinembedded sections: A novel pan pre-B and B- cell marker. Am J Surg Pathol. 2002.26(10):1343-50.

11. Adams B, Dorfler P, Aguzzi A, Kozmik Z, Urbanek P, Maurer-Fogy I, et al. Pax-5 encodes the transcription factor BSAP and is expressed in B lymphocytes, the developing CNS , and adult testis. Genes Dev. 1992. 6(9):1589-607.

12. Falini B, Mason DY. Proteins encoded by genes involved in chromosomal alterations in lymphoma and leukemia: Clinical value of their detection by immunocytochemistry. Blood. 2002; 99(2):409-26.

13. Lang D, Powell SK, Plummer RS, Young KP, Ruggeri BA. PAX genes: Roles in development, pathophysiology, and cancer. Biochem Pharmacol. 2007; 73(1):1-14.

14. Mhawech-Fauceglia $P$, Saxena R, Zhang $S$, Terracciano L, Sauter G, Chadhuri A, et al. Pax5 immunoexpression in various types of benign and malignant tumours: A high-throughput tissue microarray analysis. J Clin Pathol. 2007. 60(6):709-14.

15. Nutt SL, Eberhard D, Horcher M, Rolink AG, Busslinger M. Pax5 determines the identity of $B$ cells from the beginning to the end of $\mathrm{B}$ lymphopoiesis. Int Rev Immunol [Internet]. 2001. Jan 1;20(1):65-82. Available from: https://doi.org/10.3109/08830180109056723

16. McCune RC, Syrbu SI, Vasef MA. Expression profiling of transcription factors Pax-5, Oct-1, Oct-2, BOB.1, and PU.1 in Hodgkin's and nonHodgkin's lymphomas: a comparative study using high throughput tissue microarrays. Mod Pathol an Off J United States Can Acad Pathol Inc. Jul 2006;19(7):1010-8.

17. Chu PG, Loera S, Huang $Q$, Weiss LM. Lineage Determination of CD20 - B-Cell Neoplasms An Immunohistochemical Study. Am J Clin Pathol. 2006; 126:534-44.

18. O'Malley DP, Dogan A, Fedoriw Y, Medeiros LJ, Ok CY, Salama ME. American Registry of Pathology Expert Opinions: Immunohistochemical evaluation of classic Hodgkin lymphoma. Ann Diagn Pathol. 2019. 39:105-10.

19. Huh J. Epidemiologic overview of malignant lymphoma. Korean J Hematol. 2012. 47(2):92104.

20. Borgohain M, Krishnatreya K, Weingken CK, Das JK. Diagnostic Utility of Immunohistochemistry in Lymphoma Section. Int J Contemporary Med Res. 2017. 4(12):6-9.

21. Ward E, DeSantis C, Robbins A, Kohler B, Jemal A. Childhood and adolescent cancer statistics, 2014. CA Cancer J Clin. 2014. 64(2):83-103.

22. Mohammedzaki LB, Hasan KM, Polus RK, Yassin AK. Clinicopathological, 
immunohistochemical charachtaristic and the outcome of Hodghkin lymphoma patients in Erbil city, Iraq. Iraqi J Hematol. 2019; 8:14-20.

23. Albasri AM, El-Siddig AA, Shah A, Alhujaily AS, Hussainy AS, Alhujaily AS. Pattern of Lymph Node Pathology in Western Saudi Arabia. Asian Pacific J Cancer Prev. 2014;15(11):4677-81.

24. Shabbir S, Ahmed KN, Marri $M$, Jan $M H$, Jamali MS, Khanum S, et al. Epidemiological features of Lymphoma in Pakistan. Pure Appl Biol. 2019. 8(1):977-94.

25. Punnett A, Tsang RW, Hodgson DC. Hodgkin Lymphoma Across the Age Spectrum: Epidemiology, Therapy, and Late Effects. Radiat Oncol [Internet]. 2010. 20(1):30-44. Available from:http://dx.doi.org/10.1016/j.semradonc.2009. 09.006

26. Fadhil MS, Al-Nueimy WM, Lazim AF. Hodgkin's lymphoma. An immunohistochemical profile in northern Iraq. Saudi Med J. May 2014.;35(5):448-53.

27. Al-shemmari $\mathrm{SH}$, Al-humood $\mathrm{S}$, Ameen R. Hodgkin's Disease: Kuwait Experience. Med Princ Pract. 2004; 13(4):201-5.

28. Shi Y, Li X. [Clinicopathologic features and association with Epstein-Barr virus infection in 235 cases of Hodgkin lymphoma from northern China]. Zhonghua bing li xue za zhi $=$ Chinese $\mathrm{J}$ Pathol [Internet]. 2015. 44(2):84-89. Available from:http://europepmc.org/abstract/MED/259166 37

29. Zhou L, Deng Y, Li N, Zheng Y, Tian T, Zhai Z, et al. Global, regional, and national burden of Hodgkin lymphoma from 1990 to 2017: estimates from the 2017 Global Burden of Disease study. J Hematol Oncol [Internet]. 2019.12(1):107. Available from: https://doi.org/10.1186/s13045-019-0799-1

30. Yildirim R, Sincan G. The clinicopathologic features and response to treatment of patients with Nonhodgkin Lymphoma: A single-center experiment in Turkey. Pak JMed Sci. 2019; 35(1):82-5.

31. Saadoon H, Alhilfi Q, Mansib O, Kassib K, Jihad $\mathrm{H}$, Jihad $\mathrm{I}$, et al. Patterns of lymphoma in Misan city, Iraq: A retrospective observational study. F1000 Research. 2019; 8(1733):8-13.

32. Khader YS, Sharkas GF, Arkoub KH, Alfaqih MA, Nimri OF, Khader AM. The Epidemiology and Trend of Cancer in Jordan , 2000 - 2013. J Cancer Epidemiol. 2018; 2018:1-7.

33. Jafari-delouei $N$, Naimi-tabiei $M$, Fazel $A$, Ashaari M, Hatami E. IRANIAN Descriptive Epidemiology of Lymphoma in Northern Iran: Results from the Golestan Registry $2004-2013$. Arch Iran Med. 2020; 23(3):150-4.

34. Yaqo RT, Hughson MD, Sulayvani FK, AlAllawi NA. Malignant lymphoma in northern Iraq:
A retrospective analysis of 270 cases according to the World Health Organization classification. Indian J Cancer. 2011; 48(4):446-51.

35. Urquhart A, Berg R. Hodgkin's and nonHodgkin's 'lymphoma of the head and neck. Laryngoscope. 2001; 111(9):1565-9.

36. Ranuhardy D, Suzanna E, Sari RM, Hadisantoso DW, Andalucia R, Abdillah A. CD30, CD15, CD50, and PAX5 Expressions as Diagnostic Markers for Hodgkin Lymphoma $(\mathrm{HL})$ and Systemic Anaplastic Large Cell Lymphoma (sALCL). Acta Med Indones. 2018; 50(2):104-9.

37. Al-Diab Al, Siddiqui N, Sogiawalla FF, Fawzy EM. The changing trends of adult Hodgkin's disease in Saudi Arabia. Saudi Med J. 2003;24(6):617-22.

38. Aljufairi EA, George SM, Alshaikh SA, Radhi AA, Mohamed RM. Spectrum of lymphoma in Bahrain. A retrospective analysis according to the World Health Organization classification. Saudi Med J. 2018; 39(7):736-9.

39. Perry AM, Diebold J, Nathwani BN, Maclennan KA, Müller-Hermelink HK, Bast M, et al. Nonhodgkin lymphoma in the developing world: Review of 4539 cases from the international Non-Hodgkin Lymphoma Classification Project. Haematologica. 2016; 101(10):1244-50.

40. Khan MR, Ahmad A, Kayani N, Minhas K. Expression of PAX-5 in B cell Hodgkin and Non Hodgkin Lymphoma. Asian Pacific J Cancer Prev. 2018; 19(12):3463-6.

41. Johri N, Patne SCU, Tewari M, Kumar M. Diagnostic utility of PAX5 in Hodgkin and nonHodgkin lymphoma: A study from Northern India. J Clin Diagnostic Res. 2016; 10(6):4-7.

42. Morgan EA, Pozdnyakova O, Nascimento AF, Hirsch MS. PAX8 and PAX5 are differentially expressed in B-cell and T-cell lymphomas. Histopathology. 2013; 62(3):406-13.

43. Nguyen TDT, Frater JL, Klein J, Chen L, Bartlett NL, Foyil K V., et al. Expression of TIA1 and PAX5 in Classical Hodgkin Lymphoma at Initial Diagnosis May Predict Clinical Outcome. Appl Immunohistochem Mol Morphol. 2016; 24(6):383-91.

44. Madanagopaal LR, Subashchandrabose $P$, Sivanandam S. Analysis of PAX5 expression of Hodgkin's and non-Hodgkin's lymphomas: in comparison with routine panel. Arch Cytol Histopathol Research. 2016; 1(1):4-13.

45. Palma-Lara I, Sánchez-Aldana AE, JiménezHernández $E$, Martínez-Villegas $O$, NúñezEnríquez JC, Mejía-Aranguré JM, et al. Variable Expression of Notch1 and Pax5 in Classical Hodgkin Lymphoma and Infection with EpsteinBarr in Pediatric Patients. Microorganisms. 2020;8(6):958. 
46. Adams $\mathrm{H}$, Liebisch $\mathrm{P}$, Schmid $\mathrm{P}$, Dirnhofer $\mathrm{S}$, Tzankov A. Diagnostic Utility of the B-cell Lineage Markers CD20, CD79a, PAX5, and CD19 in Paraffin-embedded Tissues From Lymphoid Neoplasms. Appl Immunohistochem Mol Morphol. 2009; 17(2):96-101.

47. Feldman AL, Dogan A. Diagnostic uses of Pax5 immunohistochemistry. Adv Anat Pathol. 2007;14(5):323-34.

48. Zapater E, Bagán J V., Carbonell F, Basterra $\mathrm{J}$. Malignant lymphoma of the head and neck. 2010; Oral Dis. 16(2):119-28. 